\title{
Exceptionally well-preserved vegetal remains from the Upper Cretaceous of 'Lo Hueco', Cuenca, Spain
}

\author{
OSCAR CAMBRA-MOO, FERNANDO BARROSO-BARCENILLA, FRANCISCO CORUÑA AND JOSÉ MARÍA \\ POSTIGO-MIJARRA
}

\begin{abstract}
Cambra-Moo, O., Barroso-Barcenilla, F., Coruña, F. \& Postigo-Mijarra, J.M. 2013: Exceptionally well-preserved vegetal remains from the Upper Cretaceous of 'Lo Hueco', Cuenca, Spain. Lethaia, Vol. 46, pp. 127-140.

Vegetal remains are considered labile structures that quickly become decayed in ecosystems. However, certain lignified tissues (woody plants) can largely resist decomposition, becoming sometimes exceptionally well preserved. At the Upper Cretaceous site of 'Lo Hueco' (Cuenca, Spain), those woody remains (trunks and branches) with resinous material in the inner tracheids and parenchyma cells that were buried rapidly under anoxic conditions experienced a low degree of maturation, becoming exceptionally well preserved. Those woody remains deposited under oxic conditions (subaerial or sub-aquatic exposure) were more intensely biodegraded and subsequently carbonified, partially or completely mineralized in gypsum and covered by a ferruginous crust. These two modes of preservation are scarce, with silicification or carbonification processes much more common, and both can be considered as 'exceptional preservation'. Other vegetal remains, such as carbonified leaves, stems and roots, were collected in the site. The different modes of preservation depend directly on: depositional micro-environment (sandy distributary channel, muddy flood plain); and type (trunk, branch, stem, leave, root) and state (presence or absence of resinous material) of the material. The great abundance and diversity of fossils in 'Lo Hueco' identify it as Konzentrat-Lagerstätten, sequentially formed by alternated events of flooding and drying depositional events, but the exceptional quality and rarity of determinate vegetal macroremains preservation suggest that certain deposits of this site can be considered as conservation deposits. $\square$ Exceptional preservation, Fossil-Lagerstätten, fossil wood, 'Lo Hueco', Spain, Upper Cretaceous, vegetal remain
\end{abstract}

The palaeontological site 'Lo Hueco' was discovered in Cuenca, Spain, in 2007. To date, it has provided more than 8500 well-preserved Late Cretaceous macrofossils, including plants, invertebrates and vertebrates. The fossil assemblages recovered at this site, apart from plants, are mainly composed of molluscs (bivalves and gastropods), actinopterygians and teleosteans fishes, amphibians, panpleurodiran (bothremydids) and pancryptodiran turtles, squamate lizards, eusuchian crocodiles, pterosaurs, and euornithopods (rhabdodontids), theropod (mainly dromaeosaurids) and titanosaur sauropod (some of them with nearly complete skeletons) dinosaurs (Ortega et al. 2008; Barroso-Barcenilla et al. 2009a, 2010; Callapez et al. 2011). These extraordinary fossil assemblages were accumulated in a depositional environment corre- sponding to a near-coast continental muddy flood plain crossed by distributary sandy channels, exposed intermittently to brackish or marine and freshwater flooding as well as to partial or total desiccation events, and represents a relevant Fossil-Lagerstätten not only for the Iberian palaeontological record but also for the whole upper Campanian-lower Maastrichtian southwestern European record (BarrosoBarcenilla et al. 2009a; Cambra-Moo et al. 2012).

Among the abundant, diverse and well-preserved macrofossils collected at 'Lo Hueco', plants (fragments of woody trunks and branches, herbaceous stems and leaves, roots) appear mostly as carbonified fossils (carbon enrichment of organic tissues, sensu Fernández-López 2000). However, woody plants (tree trunks and some branches) usually maintain 
the original volume in part, with the interior partially or totally mineralized gypsum. Other specimens show resinous material into the lumen of their well-preserved tracheids and parenchyma cells. These two particular modes of preservation by gypsum and resin are unusual in the fossil record, being the silicification or carbonification processes much more common (Fernández-López 2000). In fact, this is the first case of wood fossilized in gypsum reported in the Upper Cretaceous European record, and one of the scarce findings in the world (Swezey et al. 1999). This study describes: (1) the biostratinomic and fossil-diagenetic characterization of the diverse plant preservation at 'Lo Hueco', describing the most representative remains and identifying the mineral species substituting the original organic matter; (2) the analysis and interpretation of the possible source of these remains, taking into account their patterns of taphonomic alteration, and their palaeoenvironmental implications (Uhl 2006); and (3) the proposal of the models that could explain the fossilization processes for the vegetal remains and the consideration of determinate stratigraphical intervals of the site as Fossil-Lagerstätten.

\section{Geological and taphonomic context}

'Lo Hueco' is located in the province of Cuenca (middle east of Spain), close to the village of Fuentes. It is situated in the southwestern branch of the Iberian Ranges on the Arcas-Fuentes Syncline, and includes an interval in 'Garumn' facies belonging to the upper part of the 'Margas, Arcillas y Yesos de Villalba de la Sierra' Formation (Vilas et al. 1982; Fig. 1A-C). In 'Lo Hueco', a stratigraphical succession of green (V), grey (G1), red (R1), grey (G2), red (R2) and brown (M) marly mudstones, separated by gradual boundaries, can be identified. This succession becomes partially modified by a first sulphated interval (S1) that cuts the level $\mathrm{V}$ by means of a net boundary, by a sandy channel structure $(\mathrm{C})$ that interrupts the levels V, G1 and $\mathrm{R} 1$ by means of an erosive surface, and by a second sulphated interval (S2) that distorts at least part of the level G2 by means of a net boundary (Barroso-Barcenilla et al. 2009a, 2010; Segura et al. 2010; Carenas et al. 2011; Cambra-Moo et al. 2012) (Fig. 1C-E).

Four of these stratigraphical lithosomes have provided the main part of the fossils from 'Lo Hueco': the structure $\mathrm{C}$, the levels G1 and G2, and the lower part of the level R2 (Fig. 1D,E). They can be defined as four taphofacies or bonebeds (sensu Rogers et al. 2007; Cambra-Moo et al. 2012). Specifically, the lithosome $\mathrm{C}$, interpreted as deposit of a distributary sandy channel, is composed of sandy conglomerates and breccias, with a relatively high proportion of clasts (mainly pebbles of silica and bone fragments of phosphates, but also soft clasts of clays and carbonates) and a low proportion of matrix and cement $(<20 \%)$, sandstones and sandy mudstones. Lithosome $\mathrm{C}$ exhibits numerous erosive surfaces and tractive deposits and has in its sandy mudstone fraction relevant proportions of quartz (30-25\%), calcite (20 $-15 \%)$, feldspar $(10-5 \%)$ and clay minerals (5540\%) (Barroso-Barcenilla et al. 2009a, 2010; González-Acebrón et al. 2010). It contains generally highly altered macrofossils (of centimetric size, fragmented and with signs of mechanical erosion processes, such as abrasion) that appear randomly distributed (Barroso-Barcenilla et al. 2009a; Cambra-Moo et al. 2009, 2012) (Fig. 2A).

The levels G1 and G2 and the lower part of the level R2, with larger (of decimetric size) and less or no eroded macrofossils, are composed of marly mudstones, with a relatively high proportion of clay minerals (>85\%), moderate proportion of gypsums $(<15 \%)$ and low proportion $(10-5 \%)$ of calcium carbonates (calcite). These levels show mainly planar or parallel bedding and locally wavy and massive bedding, and some thin sandy interbeds with crossbedding (especially in the upper part of the levels G1 and G2). Their clay minerals include illite (65-30\%), kaolinite (50-20\%), smectite $(25-0 \%)$ and chlorite (2.5-0\%) (Barroso-Barcenilla et al. 2009b, 2010; Coruña et al. 2011).

Specifically, the level G1, corresponding to the proximal part of a flooded muddy plain (close to the distributary channels), preserves an important number of totally or partially articulated specimens, mainly sauropod dinosaurs, with a low degree of scattering and a mainly parallel and perpendicular orientation to the lithosome C. The level G2 and the lower part of the level R2, interpreted as the distal part of a flooded muddy plain (distant from the distributary channels) and the partially or totally dried part of a muddy plain, respectively, by contrast, contain macrofossils that are rarely articulated and randomly scattered (Barroso-Barcenilla et al. 2009a; Cambra-Moo et al. 2009, 2012). All the stratigraphic lithosomes of this site contain a significant quantity of gypsum (Barroso-Barcenilla et al. 2009a, 2010; Carenas et al. 2011) (Fig. 2B, C).

Concerning non-plant fossil-diagenesis, invertebrates are mainly preserved as internal composite moulds of marly mudstone (bivalves) or gypsum (most of gastropods). Representing the largest part of the fossil sample, vertebrates are exclusively represented by biomineralized remains (hard parts, such as bones, teeth, plates, osteoderms and scales), which mainly retain the original structure finely preserved 

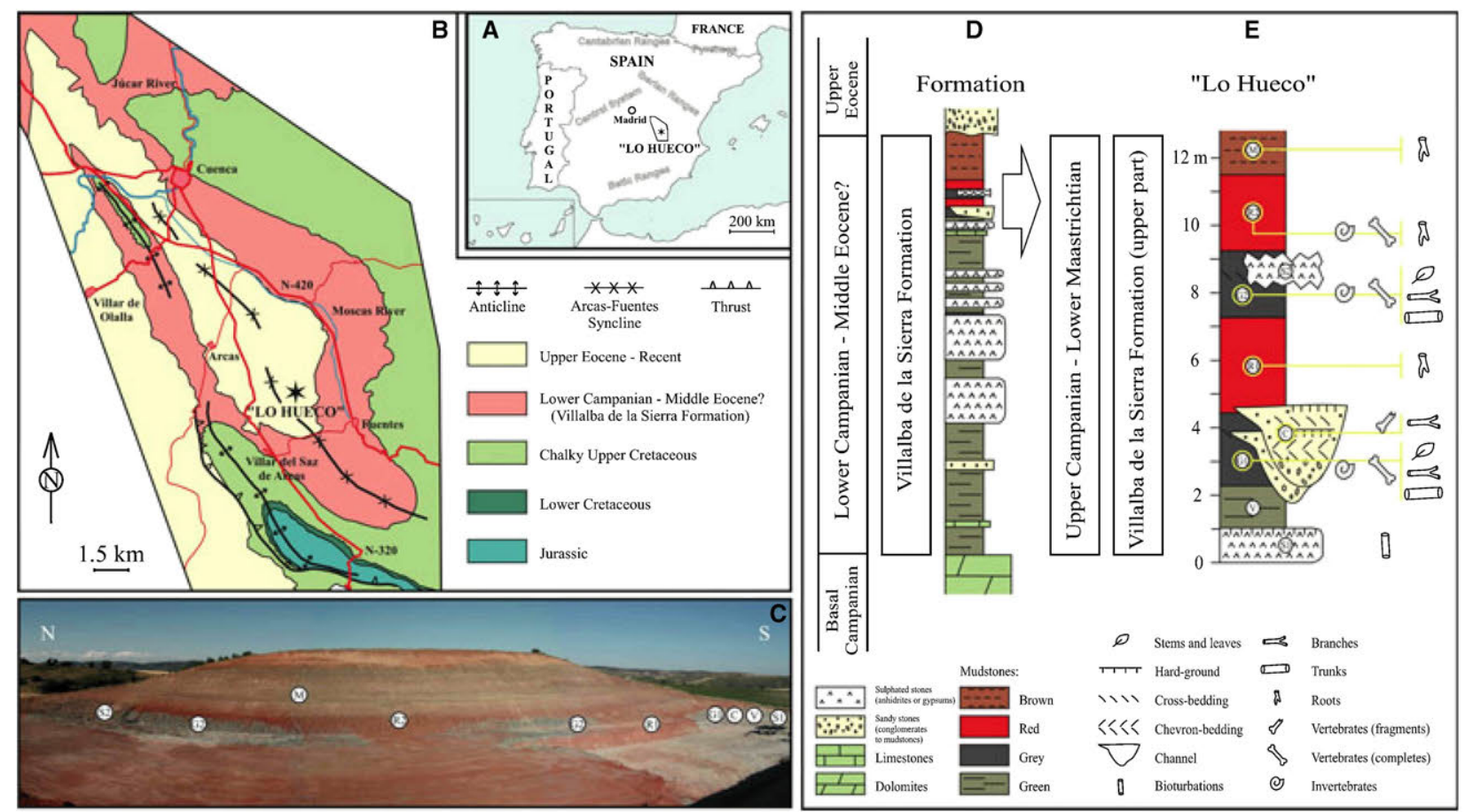

Fig. 1. General and geological setting of the palaeontological site of 'Lo Hueco'. A, geographical location. B, detailed geological situation inside the Arcas-Fuentes Syncline. C, D, sections of the Villalba de la Sierra Formation (schematic, 1C), and of the site (detailed, 1D). E. Lateral view of the eastern talus of the outcrop during the excavation phase, with the identified lithosomes.

in their interior with certain diagenetic modifications. Most of macrofossils (especially bones), present from inside to outside: 1 , a first mineralization of gypsum (in inner cavities), a ferruginous crust (covering outer surfaces, usually thicker in the fossils from the lithosome C and the level G1 than in those from the level G2 and the lower part of the level R2), and 2, a growth of gypsum crystals (covering outer surfaces and eventually crossing the ferruginous crust and first mineralization). Some fossils, almost all from the darkest deposits of the level G2, have micro-crystalline pyrite formed inside their tissues (Barroso-Barcenilla et al. 2009a; Cambra-Moo et al. 2009, 2012) (Fig. 2D-F).

\section{Materials and methods}

This work is based on field and laboratory macroscopic observations of numerous vegetal remains, and detailed microscopic, $\mathrm{X}$-ray diffraction (XRD) and X-ray fluorescence (XRF) analyses of four representative vegetal remains, numbered $\mathrm{Hu}$ 3312, Hu-8620, Hu-7719 and Hu-8114, and temporally housed in the Departamento de Paleontología of the Universidad Complutense de Madrid (UCM).

Fragments of these four specimens measuring approximately $1 \times 1 \times 2 \mathrm{~cm}$ have been processed to provide thin sections of approximately $25-35 \mu \mathrm{m}$ thick. The standard sections (transverse, radial longitudinal and tangential longitudinal orientations) have been prepared at the Laboratorio de Petrología y Geoquímica of the UCM. In total, 12 thin sections have been observed under transmission light microscopy using an Olympus $\mathrm{B} \times 50$ series optical microscope equipped with UIS lenses (magnification $\times 50, \times 100, \times 200$ and $\times 500)$. Images have been captured with a Leica Application Suite V3.2.0 and processed using Adobe Photoshop CS3. All the samples have been described using the list of the features of the IAWA Committee (2004).

The mineralogical characterization of these four studied vegetal samples has been made by the XRD. This study has been performed in the Centro de Asistencia a la Investigación de Técnicas Geológicas of the UCM using a Bruker D8 Advance diffractometer provided of a detector Sol-X, with $\mathrm{Cu}-\mathrm{K} \alpha$ radiation and a graphite monochromator. The aim of the XRD study has been to characterize bulk mineralogy, using random-powder specimens that have been scanned from 2 to $65^{\circ} 2 \theta$, time by step $1 \mathrm{~s}$ and step size of $0.02^{\circ} \mathrm{q}$ scan speed. The reflective factors of Schultz (1964) have been used for the semi-quantitative analyses of bulk samples. This study has been completed using the XRF in the vegetal remains for geochemical results and in order to compare all samples to each other. The XRF study has been performed in the Centro de Asistencia a la Investigación 

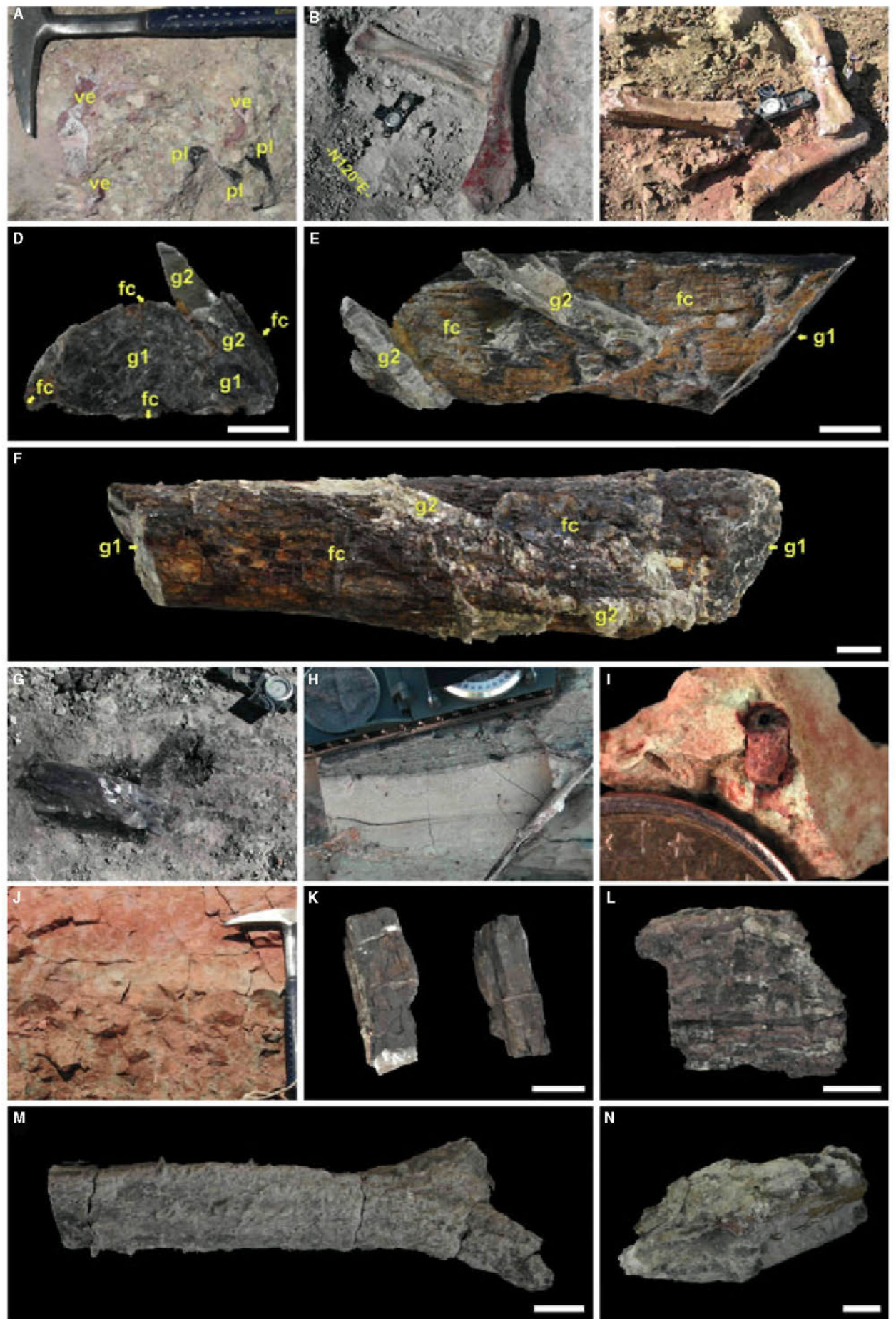

Fig. 2. Taphonomic context and vegetal remains of 'Lo Hueco'. A, plant ( $\mathrm{pl}$ ) and vertebrate (ve) remains from the lithosome C of centimetric size and highly altered. B, fossil bones from the level Gl of decimetric size, slightly altered and oriented parallel and perpendicularly to the main axis of the lithosome $\mathrm{C}\left(-\mathrm{N} 120^{\circ} \mathrm{E}-\right)$. C, bone remains from the level $\mathrm{G} 2$ of decimetric size, slightly altered and oriented parallel and randomly scattered. D, E, trunk Hu-TCM from the flooded muddy plain (levels G1 or G2) showing the first mineralization of gypsum (g1) inside, the ferruginous crust (fc) over its external surface, and the second growing of gypsum crystals (g2) affecting the ferruginous crust and the first mineralization (transversal, 2D, and longitudinal, 2E, views). F. Trunk Hu-TAH from the level G2 showing the first mineralization of gypsum ( $\mathrm{gl}$ ) inside, the ferruginous crust ( $\mathrm{fc}$ ) over its external surface, and the second growing of gypsum crystals (g2) affecting the ferruginous crust and the first mineralization. G, branch in the level G2. H. Carbonaceous remains in the level G1. I. Root (mould) in the dried muddy plain (levels R1 or R2). J, root-marks in the level R1. K, specimen Hu-3312, two pieces of branches in unaltered state of preservation. $\mathrm{L}$, specimen $\mathrm{Hu}-8620$, brown and black colours are related with presence of organic matter in wood. $\mathrm{M}$, specimen Hu-7719, fragment of thick branch or trunk. N, specimen Hu-8114, notice the limonitization processes on the surface and the strong mineralization by gypsum in the inner part. The length of the hammer is $33 \mathrm{~cm}$ and that of the compass is $15 \mathrm{~cm}$, and the diameter of the coin is $16.25 \mathrm{~mm}$. Scale bars for $\mathrm{D}-\mathrm{F}=5 \mathrm{~cm}$ and for $\mathrm{K}-\mathrm{N}=2 \mathrm{~cm}$. 
de Difracción de Rayos X of the UCM using a PANalytical Axios spectrometer of dispersion wavelength $(4 \mathrm{~kW})$.

\section{Vegetal remains}

A significant number of vegetal remains were studied during field campaigns and collected for detailed subsequent analyses. Macroremains are represented by thick trunks of decimetric-metric size, mostly from the levels G1 and G2; thin trunks and branches of centimetric-decimetric size, mostly collected in the lithosome $\mathrm{C}$ and the levels $\mathrm{G} 1$ and $\mathrm{G} 2$; carbonaceous macroremains of stems and leaves of millimetric-centimetric size, mostly collected in the levels G1 and G2; and roots and root-marks of millimetric-centimetric size, mostly from the levels R1 and R2 (Fig. 2D-J). Vegetal micro-fossils, especially well preserved in the levels G1 and G2, include palynomorphs, mainly represented by spores and pollens with a bleached aspect, probably reflecting a low grade of carbonification (Peyrot et al. 2010).

Most of the vegetal macroremains appear not especially biostratinomically altered. Except in those proceeding from the lithosome $\mathrm{C}$ (slightly affected by fragmentation), no significant indicators of abrasion nor evidences of long transportation have been clearly identified. In the same way, no signs of pyrolysis (i.e. presence of pyrofusinite sensu Stach et al. 1982; or other macroscopic evidences Scott 2010) have been observed. However, only trunks and branches show useful anatomical features for studying their characteristics in detail. It must be highlighted the existence of a first mineralization of gypsum (permineralization or cementation of internal tissues), a ferruginous crust (covering outer surfaces) and a second growing of gypsum crystals (covering outer surfaces and filling fractures) in the main part of the collected trunks and branches. Specifically, thick trunks, up-to $75 \mathrm{~cm}$ long, $25 \mathrm{~cm}$ wide and $15 \mathrm{~cm}$ height, are a bit compressed, showing carbonification and limonitization processes on their surface, and their interior partially or totally mineralized by gypsum. Neither bark nor other structures have been recognized. Thin trunks and branches exhibit a more diverse preservational pattern, comprising from exceptionally well-preserved specimens with resinous material in the lumen of their inner cells to specimens with a total mineralization by gypsum. Four of these vegetal remains (Fig. $2 \mathrm{~K}-\mathrm{N}$ ), mostly corresponding to thin trunks or branches of different lengths, diameters and states of preservation, have been studied here by mean of thin sections: $\mathrm{Hu}-3312$ and $\mathrm{Hu}-8620$ were recovered from a part of the level G1 distant from the distributary channel, whereas Hu-7719 and Hu-8114 were recovered from a part of the level Gl close to the distributary channel. Among those specimens, Hu-3312 shows the best degree of preservation and thus most of the microscopic characteristics described here are mainly referred to it, whereas $\mathrm{Hu}-8114$ exhibits the highest degree of mineralization by gypsum.

\section{Microscopic characterization}

In detail, the Hu-3312 sample shows clear anatomical features, corresponding in transverse section to wood pycnoxylic with growth rings only slightly marked. The transition from early to late wood is not abrupt, with a transition zone 1-3 (4) cells wide (Fig. 3A). The width of annual rings varies from 0.9 to $1.7 \mathrm{~mm}$. There are no resinous canals. The tracheids are thin-walled, around 3-4 $\mu \mathrm{m}$ thick, and are more or less rounded in transverse view (Fig. 3B), with a tangential diameter of $40-50 \mu \mathrm{m}$ (range 30-60 $\mu \mathrm{m}$ ). Sometimes the tracheids appear thoroughly compressed. The rays are marked and their cells are filled with dark and amorphous substances (Fig. 3B). Axial parenchyma is absent.

In tangential section, the rays of the $\mathrm{Hu}-3312$ sample are mostly uniseriate (Fig. $3 \mathrm{C}$ ), a few partially biseriate in the middle part. The cross-section of the cells is an ellipse. The average ray height is $250 \mu \mathrm{m}$, and the average ray height in number of cells is 10-25 (range 5-40). Size of the cells is slightly varying, and spiral thickenings are absent. A high amount of disorganized, elliptic to rounded, platelike structures appear in the surface of many tracheids (Fig. 3C). In radial section, the bordered pits on the radial walls are arranged in two rows (Fig. 3D), seldom in three rows; these pits are subopposite and hexagonal showing oval to orbicular apertures (Fig. 3D,E). The mean diameter of bordered pits on the radial walls is $16 \mu \mathrm{m}$. In the cross fields of the rays, the pitting is not distinctly visible (Fig. 3F). Many tracheids contain a dark carminered or sulphur-yellow, possibly resinous organic matter.

In certain points of the Hu-3312 sample, wood is slightly compressed and shows moderate evidences of distortion processes in parenchyma rays and tracheids (Fig. 4A,B). A significant degree of decay can be detected in the tracheids wall, showing dark colour and weak consistence. Carbonification processes can also be observed in some areas of wood (Fig. 4B).

The remaining samples analysed (Hu-8620, Hu7719 and $\mathrm{Hu}-8114$ ) have a poor state of preservation, and it is not possible to observe any 

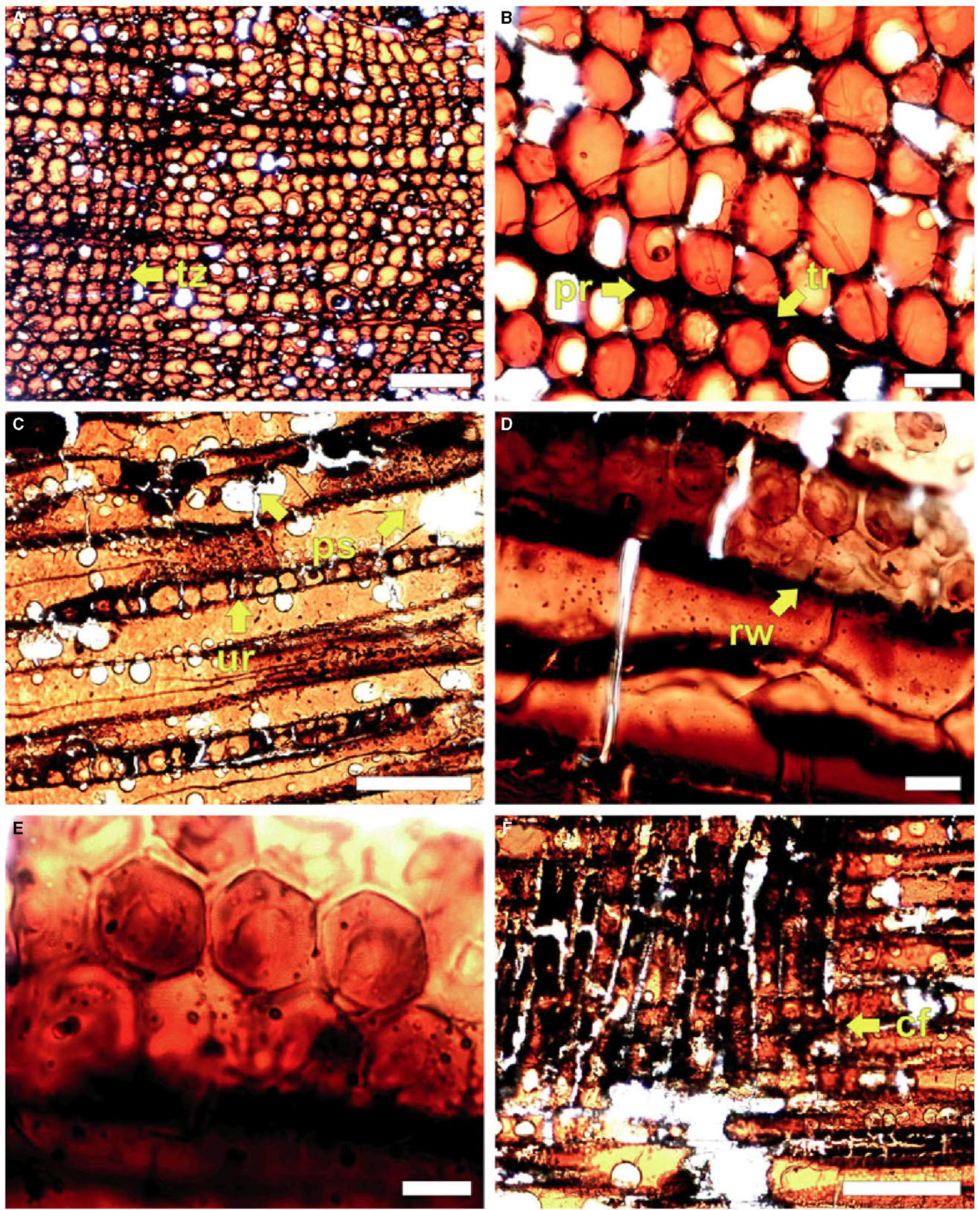

Fig. 3. Microscopic anatomical features of the specimen Hu-3312, from the level G1 (far of the lithosome C). A, transverse section, showing the transition zone (tz). B, rounded or slightly elliptic tracheids (tr) in transverse view, and the cells of the parenchyma rays (pr) containing dark substances. C, tangential section, showing uniseriate rays (ur) and plate-like structures (ps). D, tangential section, pits on the radial walls (rw) arranged in two rows. E, bordered pits with hexagonal shape and elliptic apertures in tangential view. F, radial section, in the cross fields (cf) of the rays the pitting is not distinctly visible. Scale bars for $3 \mathrm{~A}, \mathrm{~F}=200 \mu \mathrm{m}$, for $3 \mathrm{~B}=40 \mu \mathrm{m}$, for $3 \mathrm{C}=$ $100 \mu \mathrm{m}$, for $3 \mathrm{D}=20 \mu \mathrm{m}$ and for $3 \mathrm{E}=10 \mu \mathrm{m}$. 

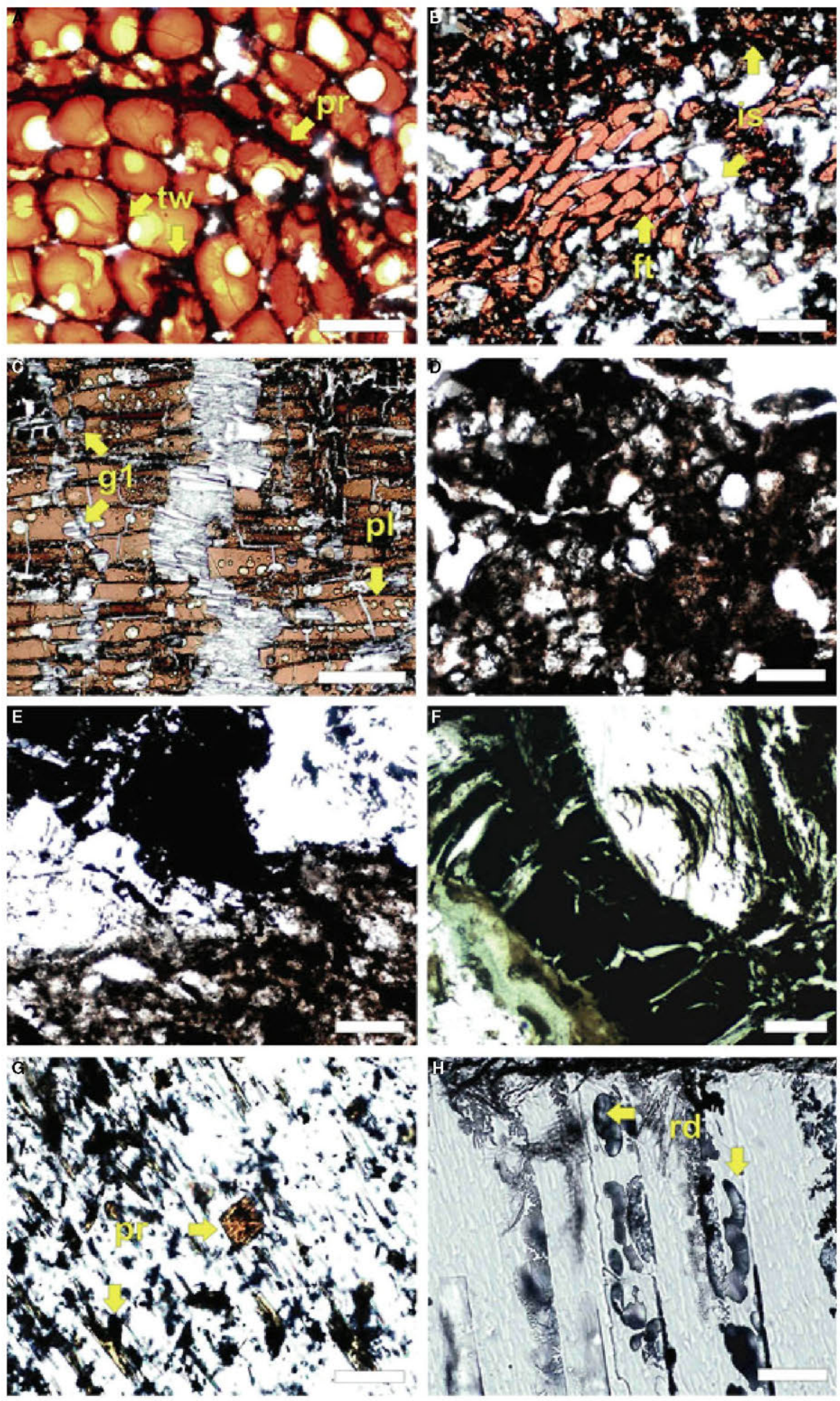

Fig. 4. Microscopic anatomical features observed in vegetal remains and taphonomic implications. A, transverse section of the Hu-3312 sample, from the level G1 (far of the lithosome C), with the wood compressed and showing distortion/deformation of the parenchyma rays $(\mathrm{pr})$ and significant biodegradation and carbonification of the tracheid walls (tw). B, transverse section, flattened tracheids (ft) in the Hu-3312 sample as a result of the pressure of sediments; biodegradation and gypsum in the intercellular spaces (is) are visible. C, radial section of the Hu-3312 sample, with the first mineralization of gypsum (g1) appearing into the tracheids, and plate-like structures (pl) in their surfaces. D, radial section of the Hu-8620 sample, from the level Gl (far of the lithosome C), showing decay in the organic tissues of the wood. E, radial section of the Hu-7719 sample, from the level G1 (close to the lithosome C). F, transverse section of the Hu-7719 sample. G, radial section, with organic matter and resinous remains ( $\mathrm{rr}$ ) in tracheids of the Hu-8114 sample, from the level G1 (close to the lithosome C), filled by gypsum. $\mathrm{H}$, radial section of the Hu-8114 sample, with presence of resinous deposits (rd) into the tracheids. Scale bars for $4 \mathrm{~A}, \mathrm{H}=50 \mu \mathrm{m}$, for $4 \mathrm{~B}, \mathrm{D}=100 \mu \mathrm{m}$, for $4 \mathrm{C}=300 \mu \mathrm{m}$ and for $4 \mathrm{E}-\mathrm{G}=80 \mu \mathrm{m}$. 
Table 1. Results (semi-quantitatives) of the XRD analyses on the bulk samples Hu-3312, Hu-8620, Hu-7719 and Hu-8114.

\begin{tabular}{lcl}
\hline Samples & Gypsum (\%) & Quartz (\%) \\
\hline Hu-3312 & 100.000 & - \\
Hu-8620 & 99.902 & 0.098 \\
Hu-7719 & 99.413 & 0.587 \\
Hu-8114 & 99.146 & 0.854 \\
\hline
\end{tabular}

well-preserved tissues in these specimens (Fig. 4D$\mathrm{H})$. Only the general structure of wood, formed by replaced tracheids, can be recognized. Wood is totally mineralized in gypsum, showing only some evidences of its biological origin. This is the case of the presence of some disorganized organic matter and resinous deposits into the structure. The degree of mineralization by gypsum seems to be progressively more marked.

\section{Mineral characterization}

The results of the XRD analyses on vegetal remains, represented in Figure 5 and Table 1, show the presence of gypsum as major mineral (and the only one in the Hu-3312 sample), and of quartz as minor/trace mineral in three samples (Hu-8620, $\mathrm{Hu}-7719$ and $\mathrm{Hu}-8114$ ). The proportion of quartz reaches the highest value $(0.854 \%)$ in the $\mathrm{Hu}-8114$ sample, corresponding to that with more marked diagenetic alterations.

The results of the XRF analyses, exposed in Table 2, show the existence of amorphous phases (seemingly remains of organic material, such as carbonified structures and amber-like resins), which are specially outstanding in the Hu-3312 sample $(\leq 62.1 \%)$, coinciding to that less affected by diagenetic alterations. To this specimen also corresponds the highest ratio of $\mathrm{CaO} / \mathrm{SO}_{3}(47.39 / 38.39 \%)$ and content of $\mathrm{MgO}(2.32 \%), \mathrm{SeO}_{2}(1.29 \%)$ and $\mathrm{U}_{3} \mathrm{O}_{8}$ $(0.37 \%)$, being notably lower in the remaining samples $\left(\leq 47.49 / 50.32 \%\right.$ for $\mathrm{CaO} / \mathrm{SO}_{3} ; \leq 0.27 \%$ for $\mathrm{MgO} ; \leq 0.03 \%$ for $\mathrm{SeO}_{2} ; \leq 0.09 \%$ for $\mathrm{U}_{3} \mathrm{O}_{8}$ ), and seemingly showing direct relationships between the concentrations of these oxides and the degree of diagenetic transformations of the vegetal remain. The proportions of $\mathrm{SiO}_{2}$ reach the highest values in those samples closer to the lithosome $\mathrm{C}(3.87 \%$ in $\mathrm{Hu}-$ $7719 ; \leq 1.59$ in Hu-8114), being notably lower in the remaining samples $(\leq 0.79 \%)$. The concentrations of $\mathrm{Al}_{2} \mathrm{O}_{3}$ show a notable variability from ones samples to others (from $1.23 \%$ in $\mathrm{Hu}-7719$ to 0.06 in $\mathrm{Hu}-8114)$. The sample more affected by diagenetic alterations, $\mathrm{Hu}-8114$, has been studied by mean of two XRF analyses, corresponding to its external (ext) and internal (int) parts, which have showed similar results, with the only exception of the $\mathrm{Fe}_{2} \mathrm{O}_{3}$ (3.14\% in Hu-8114ext, and $0.99 \%$ in Hu-8114int, seemingly related to the presence of the ferruginous crust), and the $\mathrm{Al}_{2} \mathrm{O}_{3}$ (0.06 in $\mathrm{Hu}-8114$ ext, and 0.29 in Hu-8114int) samples.

\section{Discussion}

Biomineralized tissues, such as mollusc shells, arthropod exoskeletons or vertebrate bones, are the hardest and more perdurable biological structures because resistant inorganic compounds, such as calcite, aragonite or apatite, constitute them. However, even these highly resistant biomaterials usually disappear during fossilization processes (Tegelaar et al. 1989; López-Martínez \& Truyols 1994; Briggs 2003). Non-biomineralized tissues usually become quickly disappeared due to the easily degradable composition of these structures. Specifically, soft tissues preservation imply the participation of several mechanism/agents that isolate biological remains from erosive mediators, such as oxygen, water and insects, and promote the preservation of these labile structures by drastic decrease of decomposition at minimum levels (e.g. microbial mats, rapid burial, mineralization), allowing the best conditions to finally provoke the fossilization (Jørgensen 1982; Allison 1988; Briggs 2001).

Vegetal remains, as those described in this manuscript, are considered moderately labile materials and usually become quickly colonized, consumed and, finally, decayed in the main part of the environments (Kiel et al. 2009). However, certain biopolymers, such as lignin (mainly present in wood), cutin and cutan, can resist the decay process for long time (Fernández-López 2000; Talbot et al. 2012). Lignin biopolymer is a complex chemical compound that constitutes the secondary vegetal cell walls and is polymerized within hemicellulose-protein matrices, in which cellulose micro-fibrils are embedded, forming a hardly resistant structure that could further resist degradation (Boerjan et al. 2003). Nevertheless, when vegetal remains arrive to the soil, depending on which part of the plants they correspond to, the major part of organic matter starts to be decomposed to finally become part of the soil humus. Decomposition processes are related with soil abiotic (moisture, temperature, $\mathrm{O}_{2} / \mathrm{CO}_{2}$, redox potential, $\mathrm{pH}$ ), and biotic (microbial biomass, insects) components (Swift et al. 1979; Jurgensen et al. 2004). Decay rates, traditionally studied from different research fields (biochemistry, industrial production, taphonomy) are at the same time, ambient and organism dependents, and as recently studies have 
Table 2. Results of the XRF analyses on the samples Hu-3312, Hu-8620, Hu-7719, Hu-8114ext (external part) and Hu-8114int (internal part).

\begin{tabular}{|c|c|c|c|c|c|}
\hline $\begin{array}{l}\text { Compound } \\
\text { name }\end{array}$ & $\begin{array}{l}\text { Hu-3312 } \\
\text { (Sum: } 37.9 \% \text { ) }\end{array}$ & $\begin{array}{l}\text { Hu-8620 } \\
\text { (Sum: } 73.9 \% \text { ) }\end{array}$ & $\begin{array}{l}\text { Hu-7719 } \\
\text { (Sum: } 77.3 \% \text { ) }\end{array}$ & $\begin{array}{l}\text { Hu-8114ext } \\
\text { (Sum: } 76.3 \% \text { ) }\end{array}$ & $\begin{array}{l}\text { Hu-8114int } \\
\text { (Sum: } 76.4 \% \text { ) }\end{array}$ \\
\hline $\mathrm{CaO}$ & 47.39 & 47.49 & 43.94 & 44.01 & 45.90 \\
\hline $\mathrm{SO}_{3}$ & 38.39 & 50.32 & 49.73 & 50.29 & 51.60 \\
\hline $\mathrm{Fe}_{2} \mathrm{O}_{3}$ & 7.50 & 0.39 & 0.49 & 3.14 & 0.99 \\
\hline $\mathrm{MgO}$ & 2.32 & 0.27 & 0.18 & 0.10 & 0.04 \\
\hline $\mathrm{SeO}_{2}$ & 1.29 & 0.03 & 0.01 & - & - \\
\hline $\mathrm{SiO}_{2}$ & 0.79 & 0.62 & 3.87 & 1.59 & 0.92 \\
\hline $\mathrm{Al}_{2} \mathrm{O}_{3}$ & 0.45 & 0.26 & 1.23 & 0.06 & 0.29 \\
\hline $\mathrm{U}_{3} \mathrm{O}_{8}$ & 0.37 & 0.09 & - & - & - \\
\hline $\mathrm{SrO}$ & 0.29 & 0.09 & 0.06 & 0.07 & 0.05 \\
\hline $\mathrm{NiO}$ & 0.24 & 0.04 & 0.01 & 0.01 & - \\
\hline $\mathrm{CuO}$ & 0.18 & 0.03 & 0.01 & 0.03 & - \\
\hline $\mathrm{TiO}_{2}$ & 0.16 & 0.03 & 0.14 & 0.09 & 0.03 \\
\hline $\mathrm{V}_{2} \mathrm{O}_{5}$ & 0.16 & 0.04 & - & - & - \\
\hline $\mathrm{ZrO}_{2}$ & 0.16 & 0.07 & 0.03 & - & - \\
\hline $\mathrm{K}_{2} \mathrm{O}$ & 0.11 & 0.05 & 0.25 & 0.09 & 0.05 \\
\hline $\mathrm{Cl}$ & 0.08 & 0.01 & 0.01 & 0.01 & 0.01 \\
\hline $\mathrm{Na}_{2} \mathrm{O}$ & 0.08 & - & 0.03 & - & - \\
\hline $\mathrm{Y}_{2} \mathrm{O}_{3}$ & 0.03 & 0.01 & - & - & - \\
\hline $\mathrm{BaO}$ & - & - & - & - & 0.12 \\
\hline $\mathrm{ZnO}$ & - & - & 0.01 & - & - \\
\hline $\mathrm{P}_{2} \mathrm{O}_{5}$ & - & 0.15 & - & - & - \\
\hline
\end{tabular}

Sum corresponds to the percentage of the oxides of the elements belonging to the total detection range (Na-U) of the XRF analyses. The remaining percentage presumably corresponds to carbonaceous amorphous materials, as showed by XRD analyses (Fig. 5, Table 1).

evoked, are influenced by other biological factor, such as taxonomy and age, that could severely modify the decay rates during decomposition processes (Mann et al. 1990; Davis \& Briggs 1998; Dix \& Graham 2000; Brand et al. 2003; Cambra-Moo et al. 2008). Therefore, depending on internal and external factors, the major part of soft tissues becomes recycled by decomposers (saprophyte system). Nevertheless, several exceptions have been reported in which labile tissues have been preserved, it is said, fossilized (Allison 1988; Briggs 2003).

Classically, and depending on the type and the quality of the concerned structures, four main modes of preservation are recognized in the fossil record (Schopf 1975): (1) 'cellular permineralization' (or 'petrifaction'), in which anatomical details and, occasionally, even microscopic structures at cellular level, are well preserved and replicated by the infiltration of minerals; (2) "coalified or carbonified compression', in which anatomical details are preserved with distortions by enrichment in carbon (characteristic of many plants fossilized in mudstones); (3) 'authigenic preservation' (or 'cementation') that replicates structures (moulds or casts) before being compressed; and (4) 'duripartic or hard part preservation', in which biomineralized tissues (i.e. shells, skeletal remains) are preserved.

The vegetal remains of 'Lo Hueco' show different modes of preservation that seem to depend directly of the depositional micro-environment (sandy distributary channel, muddy flood plain) and the type (trunk, branch, stem, leave, root) and state (presence or absence of resinous material) of the concerned fossil, as represented in Table 3. Among the largest remains, trunks and branches, those collected from the lithosome $\mathrm{C}$ (mostly fragments of centimetricdecimetric size) mainly show their surface altered by carbonification and their interior partially or totally mineralized by gypsum. This mode of preservation, seemingly occurred under oxic conditions (BarrosoBarcenilla et al. 2009a; Cambra-Moo et al. 2012), is not easily ascribable to a unique typology of preservation because it combines external 'carbonified compression' (carbonification) that forms amorphous carbon-rich dark material in the external surface, and internal 'authigenic preservation' that has replaced completely wood tissues by gypsum deposition (sensu Schopf 1975). Concerning the remains from the levels G1 and G2, trunks of decimetric-metric size exhibit their surface altered by carbonification and limonitization and their interior partially or totally mineralized by gypsum. Due to their size, these thick trunks probably were sub-aerial or shallow sub-aquatic exposed for a long period before being buried. However, the thin trunks and branches of centimetric-decimetric size from these two levels show, at least, two different preservational patterns. On one hand, those remains deposited in the level G1, far from the distributary channel, and in the level G2 (anoxic conditions: Barroso-Barcenilla et al. 2009a; Cambra-Moo et al. 2012) exhibit their surface less carbonified and limonitized, and 
Table 3. Vegetal macroremains characteristics, origins and modes of preservation (sensu Schopf 1975).

\begin{tabular}{|c|c|c|c|c|c|c|c|}
\hline \multirow{2}{*}{$\begin{array}{l}\text { Vegetal } \\
\text { macroremains }\end{array}$} & \multirow[b]{2}{*}{ Sizes } & \multirow[b]{2}{*}{ Lithosomes } & \multirow{2}{*}{$\begin{array}{l}\text { Depositional } \\
\text { micro-environments }\end{array}$} & \multicolumn{2}{|l|}{ Taphonomy } & \multirow[b]{2}{*}{ Mineral composition } & \multirow[b]{2}{*}{ Preservation modes } \\
\hline & & & & Biostratinomy & Fossil-diagenesis & & \\
\hline \multirow[t]{2}{*}{ Thick trunks } & \multirow[t]{2}{*}{$\begin{array}{l}\text { Decimetric- } \\
\text { metric }\end{array}$} & \multirow[t]{2}{*}{$\begin{array}{r}\text { Levels G1 } \\
\text { and G2 }\end{array}$} & \multirow[t]{2}{*}{$\begin{array}{l}\text { Flooded muddy plain } \\
\text { (slow burial in mainly } \\
\text { anoxic conditions) }\end{array}$} & \multirow{2}{*}{$\begin{array}{l}\text { Slight distortion of } \\
\text { original volume } \\
\text { Internal tissues } \\
\text { partially or totally } \\
\text { mineralized }\end{array}$} & $\begin{array}{l}\text { Surface: Gypsum } \\
\text { crystals (second } \\
\text { growing); ferruginous } \\
\text { crust }\end{array}$ & \multirow[t]{2}{*}{$\begin{array}{l}\text { Seemingly similar to } \\
\text { branches from the } \\
\text { level G1 (close to } \\
\text { the lithosome C) }\end{array}$} & 'Authigenic preservation' \\
\hline & & & & & $\begin{array}{l}\text { Interior: Gypsum (first } \\
\text { mineralization); } \\
\text { carbonaceous remains }\end{array}$ & & 'Carbonified compression' \\
\hline \multirow[t]{5}{*}{$\begin{array}{l}\text { Thin trunks } \\
\text { and branches }\end{array}$} & \multirow[t]{5}{*}{$\begin{array}{l}\text { Centimetric-- } \\
\text { decimetric }\end{array}$} & Lithosome C & $\begin{array}{l}\text { Sandy distributary } \\
\text { channel (rapid burial } \\
\text { in strongly oxic } \\
\text { conditions) }\end{array}$ & $\begin{array}{l}\text { Slight distortion of } \\
\text { original volume } \\
\text { Internal tissues } \\
\text { partially or totally } \\
\text { mineralized }\end{array}$ & $\begin{array}{l}\text { Surface: Gypsum crystals } \\
\text { (second growing); thick } \\
\text { ferruginous crust } \\
\text { Interior: Gypsum (first } \\
\text { mineralization); } \\
\text { carbonaceous remains }\end{array}$ & $\begin{array}{l}\text { Seemingly similar } \\
\text { to branches from } \\
\text { the level G1 (close } \\
\text { to the lithosome C) }\end{array}$ & 'Authigenic preservation' \\
\hline & & \multirow[t]{2}{*}{$\begin{array}{l}\text { Level Gl } \\
\text { (close to the } \\
\text { lithosome C) }\end{array}$} & \multirow[t]{2}{*}{$\begin{array}{l}\text { Flooded muddy plain } \\
\text { (rapid burial in slightly } \\
\text { oxic conditions) }\end{array}$} & \multirow{2}{*}{$\begin{array}{l}\text { Slight distortion of } \\
\text { original volume } \\
\text { Internal tissues } \\
\text { partially or totally } \\
\text { mineralized }\end{array}$} & \multirow{2}{*}{$\begin{array}{l}\text { Surface: Gypsum crystals } \\
\text { (second growing); thick } \\
\text { ferruginous crust } \\
\text { Interior: Gypsum (first } \\
\text { mineralization); } \\
\text { carbonaceous remains }\end{array}$} & \multirow{4}{*}{$\begin{array}{l}\text { Crystaline phases } \\
(\sim 80-75 \%) \\
\text { Gypsum }(\sim 99 \%) \\
\text { Quartz }(\sim 1 \%) \\
\text { Amorphous phases } \\
(\sim 20-25 \%) \\
\text { Amorphous phases } \\
(\sim 65-25 \%) \\
\text { Crystaline phases } \\
(\sim 35-75 \%) \\
\text { Gypsum }(100 \%)\end{array}$} & 'Authigenic preservation' \\
\hline & & & & & & & 'Carbonified compression' \\
\hline & & \multirow{2}{*}{$\begin{array}{l}\text { Levels G1 and } \\
\text { G2 (far from } \\
\text { the lithosome } \\
\text { C) }\end{array}$} & \multirow{2}{*}{$\begin{array}{l}\text { Flooded muddy plain } \\
\text { (rapid burial in mainly } \\
\text { anoxic conditions) }\end{array}$} & $\begin{array}{l}\text { Maintenance of } \\
\text { original volume }\end{array}$ & \multirow{2}{*}{$\begin{array}{l}\text { Surface: Gypsum crystals } \\
\text { (second growing); } \\
\text { thin ferruginous crust } \\
\text { Interior: Amber resins; } \\
\text { carbonaceous remains; } \\
\text { gypsum (first } \\
\text { mineralization) }\end{array}$} & & 'Carbonified compression' \\
\hline & & & & $\begin{array}{l}\text { Internal tissues } \\
\text { exceptionally } \\
\text { well preserved }\end{array}$ & & & $\begin{array}{l}\text { 'Cellular } \\
\text { permineralization' }\end{array}$ \\
\hline $\begin{array}{l}\text { Stems and } \\
\text { leaves }\end{array}$ & $\begin{array}{l}\text { Millimetric- } \\
\text { centimetric }\end{array}$ & Levels G1 and G2 & $\begin{array}{l}\text { Flooded muddy plain } \\
\text { (rapid burial in mainly } \\
\text { anoxic conditions) }\end{array}$ & $\begin{array}{l}\text { Strong distortion } \\
\text { of original } \\
\text { volume } \\
\text { Plant debris }\end{array}$ & Carbonaceous remains & & 'Carbonified compression' \\
\hline Roots & $\begin{array}{l}\text { Millimetric- } \\
\text { centimetric }\end{array}$ & Levels R1 and R2 & $\begin{array}{l}\text { Dried muddy plain } \\
\text { (strongly oxidant } \\
\text { conditions) }\end{array}$ & Moulds & Ferruginous crust & & 'Authigenic preservation’ \\
\hline
\end{tabular}

'Exceptional preservation' modes are ascribed to trunks and branches. In the first (rarity), gypsum mineral has replaced wood tissues ('authigenic preservation'); however, the vegetal remains maintain partially the structure and almost complete volume. In the second (quality), amber resins deposited into the lumen of well-preserved tracheids and parenchyma cells ('carbonified compression') have prevented organic degradation and bioerosion. 


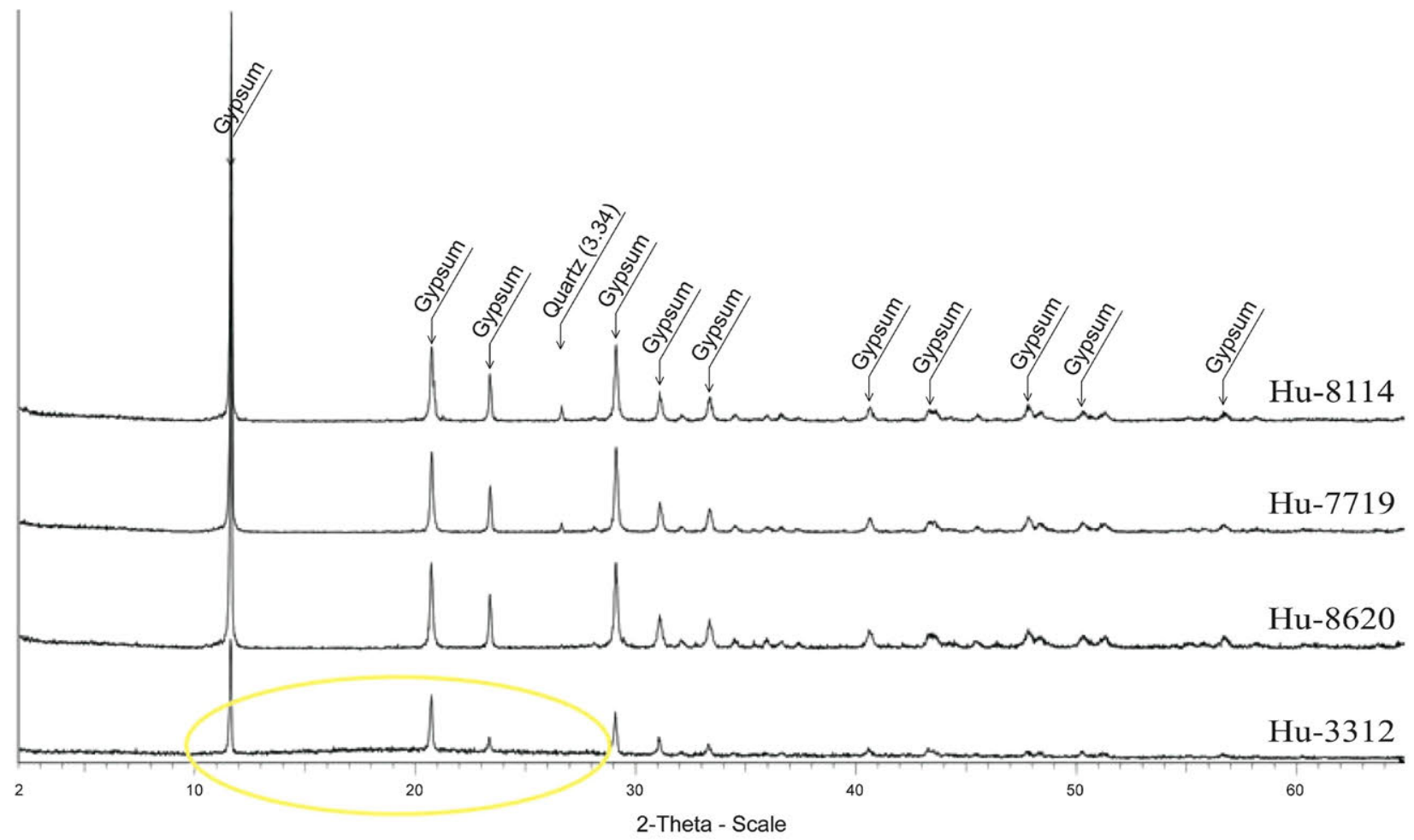

Fig. 5. X-ray diffractograms of the Hu-3312, Hu-8620, Hu-7719 and Hu-8114 samples. Note the evidences of organic matter (broad $\mathrm{X}$-ray diffraction peaks and small number of counts in the crystalline phase, and increase in the background at the diffractogram: Moore \& Reynolds 1989; circled) in the specimen Hu-3312.

their interior less replaced by gypsum. As noted in the $\mathrm{Hu}-3312$ specimen, micro-structural anatomical details of these remains are extraordinary well preserved with no or very moderate distortion ('carbonified compression' sensu Schopf 1975). In this case, the existence of resinous material in the lumen of their inner cells prevented, or at least slowed down to the minimum, the decomposition of vegetal tissues (note amber resins into the lumen of tracheids and parenchyma, Figs $3 \mathrm{~A}-\mathrm{F}, 4 \mathrm{~A}-\mathrm{C}$ ). Other parts of the same specimen show gypsum crystals in the interior of tracheids. These crystals, formed by the mechanisms of permineralization or cementation (Fig. 4B-H), are seemingly related to the early infiltration and penetration of mineral-charger water and subsequent precipitation at intracellular and interstitial spaces. Therefore, the existence of resinous material prevented further woody decay and the subsequent gypsum deposition in spaces leaved by the tissues degradation ('cellular permineralization' sensu Schopf 1975). On the other hand, those remains deposited in the level G1 close to the lithosome C (slightly anoxic conditions) usually show their surface progressively more affected by carbonification and limonitization and their interior gradually more mineralized by gypsum, and present an increasing content of quartz in their composition.
As observed in the Hu-8620, Hu-7719 and Hu-8114 specimens, these remains present a poor stage of preservation in which micro-structures details are not clearly observed (Fig. 4D-H). They show more altered wood tissues in which probably the decomposition processes reached advanced stages permitting the ulterior gypsum mineralization of nearly all structures. In these specimens, small portions of disorganized organic matter and resinous deposits are observable as little reminiscences of original biological structures. The smallest remains (millimetriccentimetric size), stems and leaves, collected from the levels G1 and G2, are forming plant debris beds, similar to those described by Oldham (1976) and Sweetman \& Insole (2010), and are principally preserved as carbonified remains ('carbonified compression' sensu Schopf 1975). Finally, roots and root-marks of millimetric-centimetric size from the levels R1 and R2 are preserved as moulds composed of ferruginous minerals ('authigenic preservation' sensu Schopf 1975).

Certain vegetal histological characteristics, such as ring width, latewood format, falserings, traumatic tissues, ray dimensions, vessel size or bark thickness, have the potential to record several aspects of where plants or trees grew up (Chapman 1994). Regarding the possible origin and palaeoenvironmental impli- 
cations of the vegetal remains collected in ' $\mathrm{Lo} \mathrm{Hu}$ eco', taking into account that displacements of a maximum of approximately $10 \mathrm{~km}$ have been described in continental environments (MacGinitie 1969; Rich 1989; Spicer 1991), these macrofossils can be assumed as native to the basin (autochthonous elements and demic organisms sensu Fernández-López 1990). As indicated by Sweetman \& Insole (2010), many of the larger vegetal fragments (trunks and branches) must there have been transported from the immediate vicinity of the depositional site, being their source in nearby upland regions. The poor degree of sorting of the plant material, the preservation of delicate vegetal and animal structures, and the rarity of large tree-like root systems in 'Lo Hueco' support that the transport distances were short, and that they were derived from areas close to the site of deposition and burial. This is also valid for a part of the carbonaceous macroremains present in 'Lo Hueco' that resemble to those attributed by Alvin et al. (1981) and Sweetman \& Insole (2010) to forest floor litter eroded and concentrated by flood deposits. Nevertheless, the presence of small roots and root-marks in the partially or totally dried part of the muddy plain (levels R1 and R2) supports that the origin of other part of the carbonaceous macroremains (stems) collected in 'Lo Hueco' could be in the herbaceous vegetation that seemingly covered the flood plain during the loss of the water by infiltration, drainage, evaporation or a combination of them.

The term 'exceptional preservation' has usually been used to refer those remains in the fossil record that contain large biological reminiscence from past organisms (Briggs 2001). However, to be well preserved (i.e. anatomically) is not the only characteristic need to be catalogued as exceptional, but also the quality (e.g. chemical preservation) or the particularity of the structures preserved (e.g. feathers, stomach contents), and the portion of the extinct biota preserved in a palaeontological site. This definition coincides to the woody remains collected in the levels G1 and G2 of 'Lo Hueco' with extraordinary well-preserved anatomical structures (macro and microscopic in which cell details are observable) and resinous material in the lumen of their tracheids (e.g. Hu-3312 sample; which could indicate the preservation of the chemical composition, as proposed by Marynowski et al. 2007), which can be considered as a mode of 'exceptional preservation' by the quality of the tissues registered. Additionally, the extraordinary peculiarity of the trunks and branches with the surface carbonified and limonitized and the interior partially or totally mineralized in gypsum (e.g. Hu-TCM, Hu-TAH, Hu-7719, Hu-8114 sam- ples) allow to also consider them as other mode of 'exceptional preservation', which could be characterized by its rarity in the fossil record (whereas silicification and carbonification are much more common).

Palaeontological sites with extraordinary richness or completeness of fossils are normally designed as Fossil-Lagerstätten. These terms can be typically assigned to those sites in which the 'concentration' (i.e. extraordinary abundance) or the 'conservation' (i.e. particularly well-preserved structures that could imply the preservation of very labile soft tissues, such as fish eyes: Gupta et al. 2008) of fossils can be qualified as exceptional (Seilacher et al. 1985). The first ones, named Konzentrat-Lagerstätten (or concentration deposits), can be associated with condensation or placer deposits and catastrophic events (e.g. rapid burial: Briggs 2001), and contain dense concentrations of disarticulated organic hard parts, such as a bonebed sensu Rogers et al. (2007). The second ones, named Konservat-Lagerstätten (or conservation deposits), correspond to those deposits in which preservation retains complete organism information. In this sense, 'Lo Hueco' could be considered as a Konzentrat-Lagerstätten that was sequentially formed by alternated events of flooding and drying depositional environments (BarrosoBarcenilla et al. 2009a,b, 2010; Cambra-Moo et al. 2012), seemingly related to the marked droughts and seasonality in the Late Cretaceous terrestrial ecosystems (Shipman 1975; Rogers 2005). Additionally, certain lithosomes of 'Lo Hueco' (levels G1 and G2) could be considered as Konservat-Lagerstätten deposits (or conservation deposits) due to the quality (sensu Marynowski et al. 2007, which will be analysed in further investigations) and the particular mode of preservation (rarity) of the fossils present in them.

\section{Conclusions}

The richness of remains at 'Lo Hueco', the diversity of taxa identified, the peculiarity of preservation stages of the macrofossils, and the high quality of the macro- and micro-structures of the biological tissues preserved have permitted us to reveal several extraordinary fossil assemblages in the Iberian Upper Cretaceous record (Barroso-Barcenilla et al. 2009a,b; Cambra-Moo et al. 2012). Despite fossilization processes normally imply the complete destruction of soft tissues, in this type of palaeontological sites, the results shown in the present case offer other information, allowing us to enrich our palaeoenvironment reconstruction, and confirming 
the occurrence of exceptionally well-preserved vegetal tissues.

In 'Lo Hueco', those woody remains rapidly buried and/or decayed in micro-environments of the site with reducing (anoxic) conditions (part of the level G1 distant from the lithosome C, and level G2, which show numerous dark deposits with microcrystalline pyrite indicative of early anoxia in the sediment: Canfield \& Raiswell 1991) experienced a variable degree of carbonification becoming exceptionally well preserved, especially when resinous material was present in the interior of their structures. On the contrary, those vegetal remains not rapidly buried, and thus with long sub-aerial or shallow sub-aquatic exposure, and/or decayed in micro-environments with oxic conditions (lithosome $\mathrm{C}$, and adjacent part of the level G1) became degraded by insect, bacterial or fungal attack and/or oxidation. This situation continued until the permeation of tissues with fluids enriched in silica, ferruginous oxides and, very especially, sulphates and the subsequent and progressive permineralization and certain replacement of quartz and, mostly, gypsum (first mineralization of this mineral, presenting selenite morphology) inside and hematite and goethite over the surface, stopped the degradation and began the transformation and replication processes, allowing to support the increasing lithostatic pressure. Subsequently, seemingly during late diagenesis, the distortion and fracturation (possibly related to tectonic efforts and/or lithostatic decompression), the limonitization of the external ferruginous crust and the second growing of gypsum crystals (presenting satin-spar and selenite morphologies, and eventually passing through the external ferruginous crust and the first mineralization) took place.

Acknowledgements. - The authors recognize the useful comments of Dr Sixto Fernández-López (Universidad Complutense de Madrid, Spain). They also appreciate the work of the reviewers of the original manuscript. Part of this research has been financed and carried out within projects PEII11-0237-7926 of the Junta de Castilla-La Mancha, and CGL2009-10766, CGL200912008 and CGL2011-25894 of the Ministerio de Ciencia e Innovación, Spain.

\section{References}

Allison, P.A. 1988: The role of anoxia in the decay and mineralization of pertinacious macrofossils. Paleobiology 14, 139-154.

Alvin, K.L., Fraser, C.J. \& Spicer, R.A. 1981: Anatomy and palaeoecology of Pseudofrenelopsis and associated conifers in the English Wealden. Palaeontology 24, 759-778.

Barroso-Barcenilla, F., Cambra-Moo, O., Escaso, F., Ortega, F., Pascual, A., Pérez-García, A., Rodríguez-Lázaro, J., Sanz, J.L., Segura, M. \& Torices, A. 2009a: New and exceptional discovery in the Upper Cretaceous of the Iberian Peninsula: the palaeontological site of 'Lo Hueco', Cuenca, Spain. Cretaceous Research 30, 1268-1278.
Barroso-Barcenilla, F., Cambra-Moo, O., Carenas, B., Coruña, F. \& Domingo, L.. 2009b: First mineralogical and geochemical overview and interpretation of 'Lo Hueco' vertebrate site (Upper Cretaceous, Cuenca, Spain). Journal of Vertebrate Paleontology 29, Suppl. 3, 59.

Barroso-Barcenilla, F., Cambra-Moo, O. \& Segura, M. 2010: Estudio preliminar sobre Geología y Tafonomía del yacimiento paleontológico de 'Lo Hueco' (Cretácico Superior, Cuenca, España). Boletín de la Real Sociedad Española de Historia Natural, Sección Geológica 104, 57-70.

Boerjan, W., Ralph, J. \& Baucher, M. 2003: Lignin biosynthesis. Annual Review of Plant Biology 54, 519-546.

Brand, L.R., Hussey, M. \& Taylor, J. 2003: Decay and disarticulation of small vertebrates in controlled experiments. Journal of Taphonomy 1, 69-95.

Briggs, D.E.G. 2001: Exceptionally preserved fossils. In Briggs, D.E.G. \& Crowther, P.R. (eds): Palaeobiology II, 328-332. Blackwell Science Publications, Oxford.

Briggs, D.E.G. 2003: The role of decay and mineralization in the preservation of soft-bodied fossils. Annual Review of Earth and Planetary Sciences 31, 275-301.

Callapez, P., Barroso-Barcenilla, F., Cambra-Moo, O. \& Segura, M. 2011: First mollusc data and palaeoenvironmental implications in 'Lo Hueco' vertebrate site (Upper Cretaceous, Cuenca, Spain). Journal of Vertebrate Paleontology, Supplement for the Society of Vertebrate Paleontology LXXI Meeting, 82.

Cambra-Moo, O., Buscalioni, A.D. \& Delgado-Buscalioni, R. 2008: An approach to the study of variation in early stages of Gallus gallus decomposition. Journal of Taphonomy 6, 21-40.

Cambra-Moo, O., Barroso-Barcenilla, F., Berreteaga, A., Carenas, B., Coruña, F., Domingo, L., Domingo, M.S., Elvira, A., Escaso, F., Ortega, F., Pérez-García, A., Peyrot, D., Sanz, J.L., Segura, M., Sopelana, A. \& Torices, A. 2009: First overview on preservational patterns in 'Lo Hueco' fossil site (Upper Cretaceous, Cuenca, Spain). Abstracts of the X Mesozoic Terrestrial Ecosystems Symposium, 261-262.

Cambra-Moo, O., Barroso-Barcenilla, F., Berreteaga, A., Carenas, B., Coruña, F., Domingo, L., Domingo, M.S., Elvira, A., Escaso, F., Ortega, F., Pérez-García, A., Peyrot, D., Sanz, J.L., Segura, M., Sopelana, A. \& Torices, A. 2012: Preliminary taphonomic approach to 'Lo Hueco' palaeontological site (Upper Cretaceous, Cuenca, Spain). Geobios 46, 157-166.

Canfield, D.E. \& Raiswell, R. 1991: Pyrite formation and fossil preservation. In Allison, P.A. \& Briggs, D.E.G. (eds): Taphonomy: Releasing the Data Locked in the Fossil Record, 337 -387 . Plenum Press, London.

Carenas, B., Barroso-Barcenilla, F., Berreteaga, A., Cambra-Moo, O., Coruña, F., González-Acebrón, L. \& Segura, M.. 2011: First overview on gypsum in the new and exceptional 'Lo Hueco' fossil site, (Upper Cretaceous, Cuenca, Spain). In Sampson, D.H. (ed.): Gypsum: Properties, Production and Applications, 176-190. Nova Publishers, New York.

Chapman, J.L. 1994: Distinguishing internal developmental characteristics from external palaeoenvironmental effects in fossil wood. Review Palaeobotany and Palynology 81, 19-32.

Coruña, F., Barroso-Barcenilla, F. \& Cambra-Moo, O. 2011: Clay mineral characterization of 'Lo Hueco' fossil site (Upper Cretaceous, Cuenca, Spain). Abstracts of the Euroclay 2011 Conference, 247.

Davis, P.G. \& Briggs, D.E.G. 1998: The impact of decay and disarticulation on the preservation of fossil birds. Palaios 13, 3-13.

Dix, J. \& Graham, M. 2000: Time of Death, Decomposition and Identification: An Atlas, 120 pp. CRC Press, Boca Raton.

Fernández-López, S.R. 1990: El significado de la autoctonía/aloctonía tafonómica. Comunicaciones de la Reunión de Tafonomía y Fosilización, 115-124.

Fernández-López, S.R. 2000: Temas de Tafonomía, 167 pp. Departamento de Paleontología, Universidad Complutense de Madrid, Madrid.

González-Acebrón, L., Barroso-Barcenilla, F., Cambra-Moo, O. \& Carenas, B. 2010: Exploratory diagenetic analysis on vertebrate fossils from 'Lo Hueco' site (Upper Cretaceous, Cuenca 
Spain). Journal of Vertebrate Paleontology, Supplement for the Society of Vertebrate Paleontology LXX Meeting, 97-98.

Gupta, N., Cambra-Moo, O., Briggs, D.E.G., Love, G., FregenalMarítnez, M. \& Summons, R.E. 2008: Molecular taphonomy of macrofossils from the Cretaceous Las Hoyas Formation, Spain. Cretaceous Research 29, 1-8.

IAWA Committee. 2004: IAWA list of microscopic features for softwood identification. IAWA Journal 25, 1-70.

Jørgensen, B.B. 1982: Ecology of the bacteria of the sulphate cycle with special reference to anoxic-oxic interface environments. Philosophical Transactions of the Royal Society of London, Series B 298, 543-561.

Jurgensen, M., Laks, P., Reed, D., Collins, A., Page-Dumroese, D. \& Crawford, D. 2004: Chemical, physical and biological factors affecting wood decomposition in forest soils. IRG documents 2003, IRG 35, 6-10.

Kiel, S., Amano, K., Hikida, Y. \& Jenkins, R.G. 2009: Wood-fall associations from Late Cretaceous deep-water sediments of Hokkaido, Japan. Lethaia 42, 74-82.

López-Martínez, N. \& Truyols, J.. 1994: Paleontologia: conceptos y métodos, 334 pp. Editorial Síntesis, Colección Ciencias de la Vida, Madrid.

MacGinitie, H.D. 1969: The Eocene Green River flora of northwestern Colorado and northeastern Utah. University of California Publications in Geological Sciences 83, 1-203.

Mann, R.W., Bass, W.M. \& Meadows, L. 1990: Time since death and decomposition of the human body: variables and observation in case and experimental field studies. Journal of Forensic Science 35, 103-111.

Marynowski, L., Otto, A., Zatón, M., Philippe, M. \& Simoneit, B. R.T. 2007: Biomolecules preserved in ca. 186 million year old fossil conifer wood. Naturwissenchaften 94, 228-236.

Moore, D.M. \& Reynolds, R.C. 1989: X-Ray Diffraction and the Identification and Analysis of Clay Minerals, 400 pp., Oxford University Press, Oxford.

Oldham, T.C.B. 1976: Flora of the Wealden plant debris beds of England. Palaeontology 19, 437-502.

Ortega, F., Sanz, J.L., Barroso-Barcenilla, F., Cambra-Moo, O., Escaso, F., García-Oliva, M. \& Marcos-Fernández, F. 2008: El yacimiento de macrovertebrados fósiles del Cretácico Superior de 'Lo Hueco' (Fuentes, Cuenca). Palaeontologica Nova, Publicaciones del Seminario de Paleontología de Zaragoza 8, Zaragoza, 119-131.

Peyrot, D., Barroso-Barcenilla, F., Berreteaga, A. \& CambraMoo, O. 2010: Preliminar palynological data and paleontological interpretations from 'Lo Hueco' fossil site (Upper Cretaceous, Cuenca, Spain). Journal of Vertebrate Paleontology, Supplement for the Society of Vertebrate Paleontology LXX Meeting, 145-146.

Rich, F.J. 1989: A review of the taphonomy of plant remains in lacustrine sediments. Review of Palaeobotany and Palynology $58,33-46$.

Rogers, R.R. 2005: Fine-grained debris flows and extraordinary vertebrate burials in the Late Cretaceous of Madagascar. Geology 33, 297-300.
Rogers, R.R., Eberth, D.A. \& Fiorillo, A.R. 2007: Bonebeds; Genesis, Analysis and Paleobiological Significance, $499 \mathrm{pp}$. The University of Chicago Press, Chicago.

Schopf, J.M. 1975: Modes of fossil preservation. Review of Palaeobotany and Palynology 20, 27-53.

Schultz, L.G. 1964: Quantitative interpretation of mineralogical composition from X-ray and chemical data for the Pierre Shale. US Geological Survey Bulletin Professional Paper 391C, $1-31$.

Scott, A.C. 2010: Charcoal recognition, taphonomy and uses in palaeoenvironmental analysis. Palaeogeography, Palaeodimatology, Palaeoecology 291, 11-39.

Segura, M., Barroso-Barcenilla, F., Cambra-Moo, O., Carenas, B. \& García-Hidalgo, J.F. 2010: Depositional environments in the 'Lo Hueco' palaeontological site (Upper Cretaceous, Cuenca, Spain). Carnets de Géologie 7, 230-232.

Seilacher, A., Reif, W.E. \& Westphal, F. 1985: Sedimentological, ecological and temporal patters of Fossil-Lagerstätten. Proceedings of the Royal Society of London 311B, 5-23.

Shipman, P. 1975: Implications of drought for vertebrate fossil assemblages. Nature 257, 667-668.

Spicer, R.A. 1991: Plant taphonomic processes. In Allison, P.A. \& Briggs , D.E.G. (eds): Taphonomy Releasing. The Data Locked in the Fossil Record, 71-113. Plenum Press, New York.

Stach, E., Mackowsky, M.J., Teichmuller, M., Taylor, G., Chandra, D. \& Teichmuller, R. 1982: Coal Petrology, 535 pp. Gebrüder Borntraeger, Berlin-Stuttgart.

Sweetman, S.C. \& Insole, A.N. 2010: The plant debris beds of the Early Cretaceous (Barremian) Wessex Formation of the Isle of Wight, southern England: their genesis and palaeontological significance. Palaeogeography, Palaeoclimatology, Palaeoecology 292, 409-424.

Swezey, C., Lancaster, N., Kocurek, G., Deynoux, M., Blum, M., Price, D. \& Pion, J.C. 1999: Response of Aeolian systems to Holocene climatic and hydrologic changes on the northern margin of the Sahara: a high resolution record from the Chott Rharsa basin, Tunisia. The Holocene 9, 141-147.

Swift, M.J.J., Heal, O.W. \& Anderson, J.M. 1979: Decomposition in Terrestrial Ecosystems, 323 pp. Blackwell Scientific Publications, Oxford.

Talbot, J.M., Yelle, D.J., Nowich, J. \& Treseder, K.K. 2012: Litter decay rates are determined by lignin chemistry. Biogeochemistry 108, 279-295.

Tegelaar, E.W., Leeuw, J.W., Derenne, S. \& Largeau, C. 1989: A reappraisal of kerogen formation. Geochimica and Cosmochimica Acta 58, 5115-5129.

Uhl, D. 2006: Fossil plants as palaeoenvironmental proxies, some remarks on selected approaches. Acta Palaeobotanica $46,87-100$.

Vilas, L., Mas, R., García, A., Alonso, A., Meléndez, N. \& Rincón, R. 1982: Ibérica Suroccidental. In García , A. (ed.): El Cretácico de España, 457-508. Universidad Complutense de Madrid, Madrid. 